\title{
ANALISIS LAPORAN KEUANGAN PADA PT. AKASHA WIRA INTERNATIOAL TbK. PERIODE 2015-2019 MENGGUNAKAN METODE ANGKA INDEKS
}

\author{
Radna Nurmalina $^{1}$, Eni Suasri ${ }^{2}$, Wiwin Munawaroh ${ }^{3}$ \\ Program Studi Akuntansi, Politeknik Negeri Tanah Laut \\ Jl. A. Yani Desa Panggung, Tanah Laut \\ email: radna@politala.ac.id ${ }^{1}$
}

\begin{abstract}
Abstrak
Analisis laporan keuangan PT. Akasha Wira International Tbk. merupakan keseluruhan laporan keuangan dengan tujuan untuk mengambil keputusan. Tujuan dari penelitian ini untuk menghitung dan juga untuk menganalisis laporan laba/rugi komprehensif dan laporan posisi keuangan perusahaan atau neraca pada PT. Akasha Wira International Tbk menggunakan metode angka indeks dimana tahun dasar yang digunakan adalah tahun dasar yanghanya fokus pada 1 tahun yang digunakan. Untuk perhitungan metode angka indeks menunjukan hasil yang fluktuatif. Terlihat pada hasil perhitungan laporan laba/rugi komprehensif peningkatan laba usaha tertinggi pada tahun 2016 yaitu sebesar Rp 427.828.000 atau 32,54\% dan untuk laporan posisi keuangan mengalami peningkatan tertinggi pada jumlah liabilitas dan ekuitas adalah tahun 2018 sebesar Rp 881.275.000 atau 34,91\% sehingga tingkat pertumbuhan pada perusahaan dapat dikatakan sehat karena dapat memaksimalkan penggunaan ekuitas selama 5 tahun.
\end{abstract}

Kata Kunci: Analaisis, Laporan Keuangan, Metode Angka Indeks

\begin{abstract}
The Analysis of the financial statements of PT. Akasha Wira International Tbk. is the entire financial report to make decisions. The purpose of this study was to calculate and analyze the comprehensive income statement and statement of financial position or balance sheet at PT. Akasha Wira International Tbk uses the index number methods. The base year used is the base year which only focuses on 1 year used. The calculation of the index number method shows fluctuating results. It can be seen in the calculation of the comprehensive income statement that the highest increase in operating profit in 2016 was Rp 427,828,000 or 32.54\% and for the statement of financial position, the highest increase in total liabilities and equity was in 2018 amounting to $R p 881,275,000$ or $34,91 \%$ so that the growth rate of the company can be said to be healthy because it can maximize the use of equity for 5 years.
\end{abstract}

Keywords: Analysis, Financial Statement,Index Number Methods.

\section{PENDAHULUAN}

Laporan keuangan adalah proses akhir dari serangkaian proses pencatatan data transaksi bisnis. Laporan keuangan perusahaan juga berfungsi sebagai kesimpulan dari pencatatan transaksi yang dilakukan oleh suatu perusahaan dan juga harus disusun berdasarkan Standar Akuntansi Keuangan (SAK) yang telah ditetapkan oleh Ikatan Akuntan Indonesia (IAI). Tujuan dari membuat laporan keuangan untuk menyediakan sebuah informasi mengenai kinerja suatu entitas, yang bermanfaat untuk sebagian besar pengguna untuk mengambil keputusan ekonomi.

Laporan keuangan menyajikan informasi keuangan seperti: (1) Laporan laba/rugi komprehensif yang memberikan informasi tentang tingkat keberhasilan operasi perusahaan dalam periode tertentu; (2) Laporan posisi keuangan berfungsi untuk melaporkan harta, hutang, dan modal yang menggambarkan posisi keuangan suatu perusahaan; (3) Laporan perubahan modal merupakan laporan yang menyajikan jumlah aset suatu perusahaan yang timbul atas transaksi selama periode tertentu; (4) Laporan arus kas dimana memiliki fungsi untuk mencatat sumber penerimaan maupun pengeluaran kas berdasarkan aktivitas operasi, investasi, dan pembiayaan. Agar mendapatkan informasi penting dari sebuah laporan keuangan, maka diperlukan analisis untuk menilai kinerja perusahaan. Analisis laporan keuangan adalah metode dimana membantu 
untuk mengambil keputusan untuk mengetahui kelebihan dan kekurangan perusahaan dimana dapat dilihat dari informasi yang didapat dari laporan keuangan tersebut. Sedangkan menganalisis laporan keuangan merupakan penilaian kinerja perusahaan, baik secara internal maupun eksternal dimana akan dibandingkan dengan perusahaan lain yang berada dalam industri yang hampir sama. Keadaan ini sangat berguna untuk perkembangan perusahaan dengan mengetahui seberapa efektif operasi perusahaan telah berjalan. Analisa laporan keuangan ini untuk mengetahui perkembangan laba pada setiap tahun mulai dari tahun 2015 sampai dengan 2019, sehingga perusahaan dapat membuat langkah dan kebijakan bila menghadapi fluktuatif pertumbuhan keadaan keuangan perusahaan.

PT. Akasha Wira International Tbk. merupakan entitas yang bergerak dalam bidang manufaktur yang didirikan pada tahun 1985. Perseroan ini memproduksi air minum kemasan pada tahun 1986, sedangkan perdagangan produk kosmetika dimulai pada tahun 2010. Kantor pusat PT. Akasha Wira International Tbk berlokasi di Perkantoran Hijau Arkadia, Jl Letjend. T.B Simatupang Kav.88, Jakarta 12520 Indonesia. Berdasarkan dapat dianalisis tingkat kecenderungannya dengan menggunakan metode angka indeks yang bertujuan untuk mengetahui tendensi atau kecenderungan keadaan keuangan suatu perusahaan dimasa yang akan datang baik kecenderungan naik, turun maupun tetap dengan melihat presentase per-komponen .

\section{TINJAUAN PUSTAKA}

\subsection{Analisis Laporan Keuangan}

\subsubsection{Pengertian Analisis Laporan Keuangan}

Menurut (Dwi Prastowo dan Rifqa Julianty, 2005), kata analisis diartikan sebagai penguraian dan penelaahan bagian itu sendiri serta hubungan antar bagian untuk memperoleh pengertian yang tepat dan pemahaman arti keseluruhan. Menurut (Harahap, 2016) analisis laporan keuangan adalah penguraian pos-pos menjadi bagian terkecil pada informasi laporan keuangan yang mempunyai makna untuk dapat disimpulkan. Analisis laporan keuangan adalah hasil pemeriksaan dari sebuah laporan keuangan untuk menentukan posisi dari laporan tersebut dan hasil operasi serta perkembangan perusahaan yang bersangkutan.

Berdasarkan pemaparan tersebut dapat disimpulkan bahwa analisis laporan keuangan adalah metode yang digunakan untuk pemeriksaan menyeluruh terhadap laporan keuangan kedalam unsur-unsurnya dan menelaah dari masing-masing unsur tersebut. Analisis laporan keuangan juga digunakan dalam mengambil keputusan untuk mengetahui seberapa efektif kinerja perusahaan dalam periode tertentu, dimana hal ini akan menentukan arah perkembangan perusahaan.

\subsubsection{Tujuan dan Manfaat Analisis Laporan Keuangan}

Secara umum, tujuan dan manfaat dilakukannya analisis laporan keuangan menurut (Hery, 2016) adalah:

1. Untuk mengetahui kinerja keuangan suatu perusahaan pada periode tertentu baik aset, kewajiban, ekuitas, maupun hasil usaha yang telah dicapai dalam beberapa periode.

2. Untuk mengetahui kelemahan suatu perusahaan sehingga hal tersebut yang menjadi kekurangan perusahaan tersebut.

3. Untuk engetahui kelebihan yang menjadi keunggulan perusahaan.

4. Untuk mengetahui langkah yang harus diperbaiki untuk kedepannya.

5. Melakukan suatu penilaian kinerja manajemen perusahaan dimana hal ini digunakan sebagai pembanding dengan entitas sejenis atau lainnya, terutama mengenai hasil yang sudah dicapai.

\subsection{Laporan Laba/Rugi Komprehensif}

Laporan laba/rugi komprehensif menurut (Najmudin, 2011) merupakan laporan yang melakukan perbandingan pendapatan dengan beban yang dikeluarkan guna menentukan laba/rugi bersih suatu entitas. Laporan ini memberikan sebuah info pada hasil akhir suatu entitas selama periode tertentu. Menurut (Dr.Kasmir, 2018) laporan laba/rugi komprehensif adalah laporan yang menunjukan keadaan suatu perusahaan dalam periode tertentu. Sedangkan Menurut (Hanatang, 2018) laporan laba/rugi komprehensif merupakan laporan yang menyajikan hasil dari keuntungan dari entitas dalam bentuk pendapatan, beban, laba ataupun rugi bersih dalam satu periode akuntansi. Artinya adalah laporan ini harus dibuat dengan siklus periode untuk mengetahui 
jumlah pendapatan dan biaya yang telah dikeluarkan. Sehingga itu dapat diketahui bahwa perusahaan dalam keadaan laba atau juga bisa rugi.

Berdasarkan SAK ETAP laporan laba/rugi komprehensif adalah hasil kinerja keuangan yang menunjukan hubungan pendapatan dan kewajiban dari perusahaan. Komponen laporan laba/rugi dapat dirangkum sebagai berikut:

1. Pendapatan, hal ini terjadi atas aktivitas entitas yang sudah biasa disebut dengan penjualan, imbalan, sewa, bunga, deviden dan royalti.

2. Beban, merupakan bagian dari kerugian perusahaan yang timbul karena aktivitas transaksi dari suatu entitas, seperti misalnya beban pokok penjualan, gaji, hutang, dan penyusutan.

3. Laba atau rugi merupakan sebuah keuntungan dan kerugian yang dialami oleh perusahaan yang timbul dari segala macam transaksi yang dilakukan oleh perusahaan. Laba disini merupakan peningkatan ekuitas (aset bersih) yang berakibat pada keuntungan penjualan dari suatu yang diproduksi oleh perusahaan tersebut. Sedangkan rugi merupakan penurunan ekuitas yang dialami oleh perusahaan sehingga penurunan ini berakibat fatal pada kinerja perusahaan.

Berdasarkan pemaparan tersebut dapat disimpulkan bahwa laporan laba/rugi merupakan laporan yang menampilkan sebuah keuntungan atau bahkan kerugian dari suatu entitas. Sehingga dengan laporan laba/rugi komprehensif ini dapat dilihat kestabilan suatu perusahaan dalam keadaan sehat finansial atau bahkan dalam keadaan kurang sehat. Laporan laba/rugi komprehensif dapat memberikan informasi yang akurat terhadap kreditur dan debitur yang ingin bergabung dalam perusahaan untuk menginvestasikan modalnya kedalam perusahaan tersebut

\subsection{Laporan Posisi Keuangan}

Laporan neraca atau laporan posisi keuangan (balance sheet) yang disusun secara bersistem mengenai harta, hutang, dan modal dari sebuah organisasi atau entitas. Laporan posisi keuangan ini merupakan laporan resmi yang dibuat oleh entitas dan juga hasil akhir dari proses accounting. Laporan posisi keuangan memberikan informasi mengenai posisi keuangan (aset, kewajiban, dan ekuitas) dari suatu perusahaan. Menurut (Fahmi, 2014) laporan posisi keuangan adalah sebuah laporan yang menunjukan posisi keuangan perusahaan seperti harta, liabilitas, dan modal pemegang saham perusahaan pada periode akuntansi. Tujuan laporan posisi keuangan untuk menunjukan posisi keuangan perusahaan pada periode akuntansi, hal ini dilakukan pada masa dimana setelah tutup buku dan sisanya ditentukan pada akhir tahun kalender.

Dalam laporan posisi keuangan, terdapat pos-pos sejenis yang dikelompokkan dan dijumlahkan sehingga memiliki makna tertentu untuk kepentingan analisis. Tiga unsur utama yang tersaji dalam laporan posisi keuangan adalah aset, kewajiban, dan ekuitas. Menurut SAK ETAP (2009), 3 unsur tersebut adalah sebagai berikut:

1. Aset atau harta adalah sumber ekonomi yang dimiliki oleh perusahaan dari entitas tertentu yang diharapkan akan memberikan manfaat di kemudian hari.

2. Kewajiban adalah beban suatu entitas yang timbul akibat transaksi pada masalalu dimana beban ini menjadi kewajiban suatu entitas untuk menyelesaikannya.

3. Ekuitas merupakan sebagai besaran hak dari pemilik perusahaan pada harta perusahaan.

Berdasarkan pemaparan tersebut dapat disimpulkan bahwa laporan posisi keuangan merupakan dokumen penting yang memberikan informasi keuangan suatu entitas dalam periode tertentu. Adapun manfaat dari laporan posisi keuangan ini sebagai alat menganalisis finansial perusahaan, untuk menganalisis likuiditas, dan juga sebagai sarana untuk membaca kemampuan suatu entitas untuk melunasi kewajiban yang dimiliki oleh perusahaan terkait.

\subsection{Metode Angka Indeks}

Angka Indeks merupakan metode yang digunakan sebagai alat yang digunakan untuk membandingan dua periode atau lebih dalam kegiatan yang sama dalam kurun waktu yang berbeda dan angka indeks ini dinyatakan dalam satuan persen. Metode ini juga dapat melihat kinerja perusahaan dengan membandingkan tahun yang satu dengan tahun yang lain untuk di analisis. Hal ini dilakukan untuk melihat tingkat kecenderungan setiap tahunnya. Tujuan dari angka indeks untuk mengukur secara kuantitatif atas terjadinya perubahan dalam waktu yang berlainan, seperti mengukur perubahan harga, indeks biaya hidup, mengukur inflasi, dan masih 
banyak lagi tujuan dari angka indeks. Menurut (Setiawan, 2013) pada dasarnya angka indeks merupakan angka yang dibuat sedemikian rupa sehingga dapat digunakan untuk membandingkan kegiatan yang sama dalam waktu yang berbeda. Sedangkan menurut (Suharyadi \& Purwanto, 2017) angka indeks adalah rangka yang dipakai sebagai alat perbandingan dua atau lebih pada kegiatan yang sama untuk waktu yang berbeda dan dinyatakan dalam satuan persen.

Berdasarkan pemaparan tersebut dapat disimpulkan bahwa angka indeks adalah alat yang digunakan untuk menganalisis sebuah laporan keuangan dimana metode ini membandingkan dua periode atau bahkan bisa lebih dalam beberapa periode, dan hasil dari analisis dapat melihat kinerja suatu perusahaan dari tahun ke tahun. Hasil dari metode angka indeks dinyatakan dalam bentuk persentase yang memperlihatkan tingkat kecenderungan suatu perusahaan tersebut mengalami peningkatan atau penurunan selama tahun yang diambil.

\section{METODOLOGI PENELITIAN}

\subsection{Deskripsi Objek Penelitian}

PT. Akasha Wira International Tbk. merupakan perusahaan manufaktur yang bergerak dalam industri minuman kemasan yang sangat sering dijumpai di lingkungan sekitar. Produk yang dihasilkan oleh PT. Akasha Wira International Tbk. adalah Air mineral ADES, Air mineral Nestle Pure Life, Susu kedelai Pureal. Perseroan ini tidak hanya memproduksi minuman kemasan tetapi juga distribusi produk kosmetika yaitu produk wella, wella professional, Clairol professional, dan industri kosmetika makarizo. PT. Akasha Wira International Tbk. didirikan dengan nama PT. Alfindo Putrasetia pada tahun 1985. Kemudian pada tahun 2010, nama perusahaan mengalami perubahan menjadi PT. Akasha Wira International Tbk. yang beralamat di perkantoran hijau Arkadia Tower C Lantai 15 Jalan Letjen. TB.Simatupang Kav.88, Jakarta 12520.

\subsection{Jenis data}

Penelitian ini menggunakan data kuantitatif dalam bentuk laporan keuangan. Data yang digunaka adalah data laporan laba/rugi komprehensif, dan juga laporan posisi keuangan dimana data ini diolah kembali. Data kualitatif juga digunakan yaitu data pendapatan perusahaan PT. AKASHA WIRA INTERNATIONAL Tbk. selama 5 tahun untuk dianalisis pada artikel ini. Sumber data sekunder yang didapat dari situs resmi Bursa Efek Indonesia (www.idx.co.id). Data ini adalah data yang sudah tersusun lengkap dalam bentuk dokumen laporan keuangan perusahaan.

Data sekunder ini kemudian diolah kembali sesuai dengan data yang dibutuhkan. Teknik pengumpulan data yang digunakan dalam penelitian ini yaitu: (1) Studi Pustaka merupakan teknik pengumpulan data yang dilakukan oleh penulis dengan membaca buku, jurnal, artikel di situs resmi pada internet yang sejenis. Hal ini dilakukan untuk memperoleh data sekunder dimana data ini akan diperuntukkan sebagai objek penelitian. Data sekunder ini didapatkan melalui situs resmi Bursa Efek Indonesia secara lengkap (www.idx.co.id). (2) Dokumentasi merupakan teknik pengumpulan data yang dilakukan dengan menghimpun dan menganalisis sebuah dokumen, berupa dokumen tertulis, gambar maupun elektronik.

\subsection{Teknik Analisa Data}

Teknik analisis data yang digunakan dalam penelitian ini adalah metode angka indeks merupakan metode yang digunakan sebagai alat perbandingan dua periode atau lebih dalam kegiatan yang sama untuk kurun waktu yang berbeda dan dinyatakan dalam satuan persen. Berikut adalah rumus yang digunakan dalam menghitung metode angka indeks

$$
\mathrm{I}_{\mathrm{t}, 0}=\frac{\sum \mathrm{P}_{\mathrm{t}}}{\sum \mathrm{P}_{0}} x 100 \%
$$

Keterangan :
$\mathrm{I}_{\mathrm{t}, 0} \quad$ : Indeks pendapatan pada waktu $\mathrm{t}$ dengan periode dasar 0
$\sum \mathrm{P}_{\mathrm{t}}$ : Jumlah seluruh pendapatan pada periode $\mathrm{t}$
$\sum \mathrm{P}_{0}$ : Jumlah seluruh pendapatan pada periode dasar. 
4. PEMBAHASAN

4.1 Persentase Laporan Laba/Rugi Komprehensif 2016-2019

\begin{tabular}{|l|c|c|c|c|}
\hline \multirow{2}{*}{\multicolumn{1}{c}{ Keterangan }} & \multicolumn{4}{c|}{ Trend Persentase (\%) } \\
\cline { 2 - 5 } & $\mathbf{2 0 1 6}$ & $\mathbf{2 0 1 7}$ & $\mathbf{2 0 1 8}$ & $\mathbf{2 0 1 9}$ \\
\hline Aset Lancar & 15,67 & 6,49 & 31,78 & 27,07 \\
\hline Aset tidak Lancar & 18,83 & 44,86 & 37,21 & 25,03 \\
\hline Total Aset & $\mathbf{1 7 , 4 9}$ & $\mathbf{2 8 , 6 3}$ & $\mathbf{3 4 , 9 1}$ & $\mathbf{2 5 , 8 9}$ \\
\hline Liabilitas Jangka Pendek & $(1,96)$ & 22,83 & 31,62 & $(12,13)$ \\
\hline Liabilitas Jangka Panjang & 49,51 & 37,33 & 9,14 & $(36,85)$ \\
\hline Total Liabilitas & $\mathbf{1 7 , 9 3}$ & $\mathbf{2 8 , 4 3}$ & $\mathbf{2 2 , 9 4}$ & $(\mathbf{2 1 , 6 8 )}$ \\
\hline Ekuitas & 17,06 & 28,82 & 46,76 & 72,96 \\
\hline Jumlah Liabilitas \& Ekuitas & $\mathbf{1 7 , 4 9}$ & $\mathbf{2 8 , 6 3}$ & $\mathbf{3 4 , 9 1}$ & $\mathbf{2 5 , 8 9}$ \\
\hline
\end{tabular}

(Sumber: Data Diolah Penulis, 2021)

Berdasarkan tabel 4.2 dapat dijelaskan bahwa dengan membandingkan tahun 2016 sampai dengan 2019 pada laporan posisi keuangan menggunakan metode angka indeks menunjukkan peningkatan dan penurunan sebagai berikut:

1. Tahun 2016: Pada tahun 2016 lebih cenderung mengalami peningkatan kecuali liabilitas jangka pendek menurun sebesar $(1,96 \%)$ keadaan ini sangat berpengaruh pada hasil ekuitas nantinya meskipun hanya mengalami penurunan yang sedikit. Peningkatan ini akan berpengaruh baik bagi perusahaan seperti aset lancar dimana mengalami peningkatan sebesar 15,67\%, aset tidak lancar meningkat sebesar 18,83\%, dan ekuitas sebesar 17,06\%. Dimana pada tahun tersebut perusahaan dapat dikatakan mampu meningkatkan aset dan juga ekuitas.

2. Tahun 2017: Pada tahun 2017 terjadi peningkatan selama 5 tahun pada semua akun. Peningkatan tersebut adalah peningkatan hutang jangka panjang maupun hutang jangka pendek mengalami peningkatan sangat besar yaitu masing-masing sebesar 22,83\% dan 37,33\%, sehingga dapat diketahui pada tahun 2017 perusahaan belum mampu mengefisiensikan hutang yang digunakan oleh perusahaan.

3. Tahun 2018: Pada tahun 2018 aset mengalami peningkatan tertinggi dibandingkan dengan tahun-tahun sebelumnya yaitu sebesar 34,91\%. Meskipun terjadi peningkatan juga terhadap hutang jangka panjang keadaan ini tidak menyurutkan perusahaan untuk tetap meningkatkan ekuitas sebesar $46,76 \%$ sehingga nilai tersebut akan menghasilkan nilai yang seimbang antara total aset dan total hutang \& ekuitas.

4. Tahun 2019: Pada tahun 2019 perusahaan dapat meminimalkan penggunaan hutang dimana hutang jangka panjang dan hutang jangka pendek mengalami penurunan masing-masing sebesar $(12,13 \%)$ dan $(36,85 \%)$ sehingga akan berdampak baik bagi perusahaan dan juga ekuitas mengalami peningkatan tertinggi dibandingkan tahun-tahun sebelumnya yaitu sebesar 72,96\%. Dapat disimpulkan bahwa ditahun 2019 perusahaan paling efektif dalam meningkatkan aset, mengurangi hutang dan meningkatkan modal yang dimiliki oleh perusahaan. 


\section{KESIMPULAN}

Perhitungan dan analisis laporan keuangan menggunakan metode angka indeks pada PT. Akasha Wira International Tbk. periode 2015-2019 mengalami pertumbuhan yang berfluktuatif atau lebih cenderung mengalami peningkatan, keadaan ini disebabkan oleh tahun dasar yang digunakan hanya fokus pada 1 tahun yaitu tahun 2015 sebagai tahun dasar. Tahun-tahun berikutnya mengalami peningkatan sehingga otoomatis pada persentase pun akan mengalami peningkatan, tetapi perusahaan belum mampu meminimalkan atau mengefisiensikan liabilitas dan beban yang digunakan selama 5 tahun. PT. Akasha Wira International Tbk, berdasarkan analisa diharapkan untuk perusahaan dapat mengefisiensikan penggunaan liabilitas dan beban yang dikeluarkan agar tidak berdampak negatif bagi tingkat kesehatan finansial perusahaan.

\section{SARAN}

Berdasarkan hasil penelitian ini, penulis memberikan saran yaitu sebagai berikut : (1) Bagi PT. Akasha Wira International Tbk. Diharapkan untuk perusahaan agar dapat mengefisiensikan penggunaan liabilitas dan beban yang dikeluarkan agar tidak berdampak negatif bagi tingkat kesehatan finansial perusahaan. (2) Bagi pembaca Diharapkan bagi pembaca agar Tugas Akhir ini dijadikan sebagai acuan untuk penelitian selanjutnya apabila mengambil masalah yang sama, maka diperlukan pemahaman lebih mendalam terkait penyebab naik turunnya masing-masing komponen.

\section{DAFTAR PUSTAKA}

Dr.kasmir. (2018). In analisis laporan keuangan. Jakarta: rajawali.

Fahmi. (2014). Manajemen keuangan perusahaan dan pasar modal. Jakarta: mitra wacana media. Hanatang, p. (2018). Analisis vertikal-horizontal sebagai alat pengukuran kinerja keuangan sektor industri barang konsumsi yang terdaftar di bei tahun 2008-2017.

Harahap. (2016). Analisis kritis atas laporan keuangan. Jakarta: pt raja grasindo persada.

Herispon. (2018). Analisis laporan keuangan (financial statement analysis). Pekanbaru.

Hery. (2016). Analisis laporan keuangan (integrated and comprehensive edition ed.). Jakarta: pt grasindo.

Hery. (2016). Analisis laporan keuangan (integreted and comprehendive edition ed.). Jakarta: pt grasindo.

Najmudin. (2011). In analisis laporan keuangan. Yogyakarta: liberty.

Sugiono, \& untung. (2016). Panduan praktis dasar analisa laporan keuangan. Jakarta: pt grasindo.

Suharyadi, \& purwanto. (2017). In statistika untuk ekonomi dan keuangan modern. Jakarta: salemba empat.

\section{Biodata Penulis}

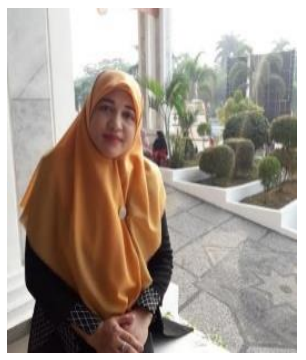

Radna Nurmalina, lahir pada tanggal 31 Mei 1970, Kota Rantau Kabupaten Tapin, Kalimantan Selatan. Penulis pada Mei 1994 menyelesaikan program Strata-1 Akuntansi di Sekolah Tinggi Malangkucecwara di Kabupaten Malang - Jawa Timur. Dan Pada Tahun 1998 penulis menyelesaikan program Starata-2 (IESP) Ilmu Ekonomi Studi Pembangunan di Universitas Negeri Syiah Kuala (UNSYIAH) di Banda Aceh Darussalam. Penulis bergabung menjadi Dosen Di Jurusan Akuntansi di Sekolah Tinggi Ilmu Ekonomi Indonesia (STIEI) Banjarmasin Di Kayu Tangi, sejak Desember 1994-2010. Pada tahun 2010 Pindah mengajar ke Politeknik Negeri Tanah Laut, karena pindah kerja mengikuti Suami, yang saat itu di fasilitasi oleh Kopertis 11 untuk pindah home base mengajarnya. Pada tahun 2010 bergabung menjadi dosen pada Program Studi D-III Teknik Informatika dan menjabat sebagai Kaprodi D-III Teknik Informatika dari tahun 2011 sampai dengan tahun 2013. Pada tahun 2017 menjadi dosen Program D-III akuntansi sampai sekarang. Penulis aktif mengajar, mengadakan penelitian dan pengabdian kepada masyarakat. Penulis dapat dihubungi melalui surel radna@politala.ac.id. 


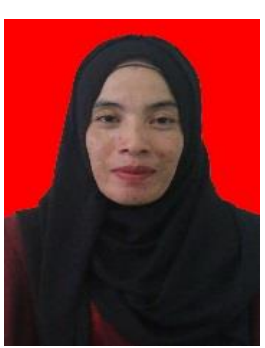

Eni Suasri, lahir di Benua Tengah, 10 Maret 1977. Menempuh pendidikan S1 Akuntansi di Sekolah Tinggi Ilmu Ekonami Nasional Banjarmasin dan lulus tahun 2004 kemudian melanjutkan S2 Manajemen di Sekolah Tinggi Ilmu Ekonomi Pancasetia Banjarmasin dan lulus pada tahun 2014. Pada tahun 2010 sampai dengan tahun 2018 penulis berprofesi sebagai staff keuangan di Politeknik Negeri Tanah Laut. Dan sejak tahun 2018 sampai sekarang penulis kemudian menjadi dosen tetap di Program Studi Akuntansi Politeknik Negeri Tanah Laut.

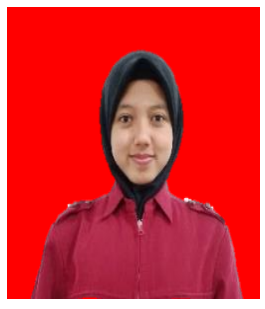

Wiwin Munawaroh, lahir di Tanah Laut 01 Januari 2000. Penulis ditahun 2018 terdaftar pada salah satu perguruan tinggi di Kabupaten Tanah Laut yaitu Politeknik Negeri Tanah Laut dan mengambil Jurusan Ekonomi dan Bisnis sampai tahun 2021. Organisasi yang diikuti penulis selama kuliah di Politeknik Negeri Tanah Laut adalah UKM FSI AL-IKHWANA (2018-2021), UKM Kewirausahaan (2018-2019). Penulis dapat dihubungi melalui surel 1801302056.akt@politala.ac.id. 